\title{
REVIEW
}

\section{Pericytes Act as Key Players in Spinal Cord Injury}

Caroline C. Picoli, ${ }^{*}$ Leda M.C. Coimbra-Campos, ${ }^{*}$ Daniel A.P. Guerra, ${ }^{*}$ Walison N. Silva, * Pedro H.D.M. Prazeres, * Alinne C. Costa, ${ }^{*}$ Luiz A.V. Magno, ${ }^{\dagger}$ Marco A. Romano-Silva, ${ }^{\dagger}$ Akiva Mintz, ${ }^{\ddagger}$ and Alexander Birbrair ${ }^{\star \ddagger}$

From the Departments of Pathology* and Mental Health, ${ }^{\dagger}$ Federal University of Minas Gerais, Belo Horizonte, Brazil; and the Department of Radiology, ${ }^{\ddagger}$ Columbia University Medical Center, New York, New York

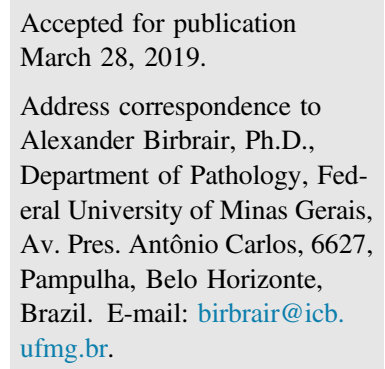

\begin{abstract}
Spinal cord injury results in locomotor impairment attributable to the formation of an inhibitory fibrous scar, which prevents axonal regeneration after trauma. The scarcity of knowledge about the molecular and cellular mechanisms involved in scar formation after spinal cord lesion impede the design of effective therapies. Recent studies, by using state-of-the-art technologies, including genetic tracking and blockage of pericytes in combination with optogenetics, reveal that pericyte blockage facilitates axonal regeneration and neuronal integration into the local neural circuitry. Strikingly, a pericyte subset is essential during scarring after spinal cord injury, and its arrest results in motor performance improvement. The arising knowledge from current research will contribute to novel approaches to develop therapies for spinal cord injury. We review novel advances in our understanding of pericyte biology in the spinal cord. (Am J Pathol 2019, 189: 1327-1337; https:// doi.org/10.1016/j.ajpath.2019.03.008)
\end{abstract}

Spinal cord injury is a serious devastating clinical condition, resulting in debilitating paralysis below the damaged level, with serious effects on the patient's life quality. ${ }^{1}$ There is a significant regional variation in the incidence of spinal cord injury; the worldwide prevalence of spinal cord lesions is between 10 and 100 individuals per million. $^{2}$ It is caused mainly by traumatic events, including gunshots, falls, sudden hyperextension injuries, disc prolapses, car crashes, or diving injuries, causing dislocation or rupture of the spinal column and leading to damage in the spinal cord. ${ }^{3}$ The spinal cord injury is characterized by catastrophic neuronal loss and axonal destruction, resulting in motor and sensory deficits. ${ }^{4}$ The degree of neurologic loss and subsequent debilitating dysfunction depend on the severity, level, and extent of lesion and whether the cord transection is partial or complete. ${ }^{5}$ Depending on the level of the spinal cord lesion, it may lead to severe complications, such as autonomic hyperreflexia, gastrointestinal and respiratory issues, hepatocellular injury, bladder dysfunction, urinary tract infections, sexual problems, and others. Current treatments for spinal cord injury are insufficient, and currently no efficient therapy is available for this condition because of its complexity. ${ }^{6}$ Consequently, it is urgent to clearly understand the detailed cellular and molecular

\footnotetext{
Supported by Instituto Serrapilheira grant Serra-1708-15285, Pró-reitoria de Pesquisa/Universidade Federal de Minas Gerais Edital grant 05/ 2016, Brazilian National Council for Scientific and Technological Development (CNPq) Universal, process 405977/2018-2, National Institute of Science and Technology in Theranostics and Nanobiotechnology process 465669/2014-0, Fundação de Amparo à Pesquisa do Estado de Minas Gerais (FAPEMIG) (Rede Mineira de Engenharia de Tecidos e Terapia Celular) grant RED-00570-16, FAPEMIG (Rede De Pesquisa Em Doenças Infecciosas Humanas E Animais Do Estado De Minas Gerais) grant RED-00313-16 (A.B.), NIH grant 1R01CA17907201A1 (A.M.), and the American Cancer Society Mentored Research Scholar grant 124443-MRSG-13-121-01-CDD (A.M.). C.C.P. and A.C.C. are supported by doctoral fellowships from Coordenação de Aperfeiçoamento de Pessoal de Nível Superior. P.H.D.M.P. is supported by a master fellowship from the Brazilian National Council for Scientific and Technological Development (CNPq).

C.C.P. and L.M.C.C.-C. contributed equally to this work.

Disclosures: None declared.
} 
mechanisms underlying spinal cord injury biology for the development of effective treatments.

\section{Spinal Cord Injury Microenvironment}

After the initial spinal cord mechanical trauma, the neuronal axis gets destroyed. This destruction is accompanied with blood-spinal cord barrier disruption and activation of glial and neuronal cells that secrete a myriad of by-products, including matrix metalloproteinases, free oxygen radicals, chemokines, and cytokines. ${ }^{7}$ The spinal cord tissue, primarily saved from the mechanical lesion, becomes vulnerable to disturbance by the effect of these toxic molecules, which drive damage in the regions that surround the original lesion site. ${ }^{8}$ Subsequently, this damage promotes the intrusion of several cell types, which via complex multicellular interactions may influence spinal cord injury outcomes. ${ }^{9}$ Various immune cells infiltrate into the injury site. ${ }^{10}$ Resident astrocytes surround the damaged area. ${ }^{11}$ Schwann cells migrate via the dorsal root, enter into the lesion epicenter, and supply the injury site milieu with growth factors. ${ }^{12} \mathrm{Fi}$ broblasts and meningeal cells also are recruited to the lesion site. ${ }^{13}$ Understanding how these cells interact may allow us to gain control or even induce reversion of the pathologic progression of spinal cord injury consequences.

Functional deficiency appears as a result of disconnection in the spinal tract in patients with spinal cord injury. This perseverates because of the disadvantageous microenvironment of the injured spinal cord for neuronal regeneration, causing inhibitory factors in the scar that develop after trauma. $^{14}$ As a result, spinal cord injury often results in permanent autonomic, motor, and sensory functional loss. ${ }^{14}$ Our current knowledge about the mechanisms involved in the scar tissue formation remains limited. Understanding what cells originate the fibrotic scar in the spinal cord is of utmost importance because gaining control of these cells may allow us to arrest or even induce reversion of scar formation after spinal cord damage. This has been the focus of recent research with the aim to accelerate the design of novel therapeutic targets for spinal cord injury recovery.

The scarring after spinal cord injury is classically referred as glial scar formation; nevertheless, it is not exclusively composed of glial cells. ${ }^{15,16}$ Several nonneural cells, including meningeal cells, ${ }^{17}$ macrophages, ${ }^{18}$ and fibroblasts, ${ }^{19}$ may participate in the generation of extracellular matrix proteins and in the sealing after spinal cord injury. Furthermore, during the cicatricial process, astrocytes, which form at the end of reactive astrogliosis, are widely considered to be the main cause of failure of new axonal growth and an unsatisfactory functional outcome. ${ }^{16}$ Reactive astrogliosis has long been considered unidirectional and irreversible in the pathology of spinal cord injury. However, the neural plasticity of reactive astrogliosis can be environment dependent, highlighting the therapeutic potential of regulating this astrocytic alteration through environmental intervention. $^{20-22}$ Interestingly, scar formation immediately after injury is essential to tissue stabilization, and without this process patients have poorer outcomes. ${ }^{15,23}$ Although some works have found that astrocyte scar formation may be proregenerative for axons, ${ }^{15,24}$ robust evidence points to the scar as a biochemical and mechanical obstacle for neuronal regeneration. ${ }^{25}$ Deciphering how its formation occurs will lead to improvement in axonal outgrowth by blocking its generation and, consequently, to better outcomes for the patients.

Multiple factors have been identified as inhibitors of the regenerative process after spinal cord injury, making them important targets for recovery induction. Chondrocyte sulfate proteoglycans produced by glial scar induce axonal death. Reduction of chondrocyte sulfate proteoglycans by administering the enzyme chondroitinase ABC effectively degrades chondrocyte sulfate proteoglycans, including neural/glial antigen 2 (expressed in pericytes), improving sensorimotor function in behavioral and electrophysiologic assessments. $^{26}$ NOGO and other receptors for RhoA-ROCK pathways promote inhibition of neuronal growth in spinal cord lesions. Blockade of NOGO-A myelin protein function with NOGO receptor antagonists ${ }^{27}$ or anti-NOGO-A antibodies $^{28}$ and inhibition of Rho-ROCK ${ }^{29}$ increase neurite outgrowth and axonal regeneration in animal studies. In addition, a transgenic mouse model that expresses human IL-37 exhibits increased myelin, neuronal preservation, and protection against locomotor deficits, indicating that this IL could be protective in spinal cord lesions. ${ }^{30}$ The exact endogenous sources of these factors remain poorly explored. Elucidating the cellular origins of these molecules will allow the development of more targeted therapies, avoiding adverse effects.

After spinal cord injury, secondary complex events take place. $^{20}$ These events include a sequence of molecular and cellular modifications that increase the severity of the lesion. $^{21}$ Among these modifications are changes in blood flow and ischemia; edema; accumulation of intracellular calcium and potassium in the extracellular space; phospholipid hydrolysis, formation of free radicals; release of excitatory amino acids, such as glutamate and aspartate; migration of inflammatory cells; microglia activation; production of inhibitory factors; and others. ${ }^{21}$ Neurons that undergo axotomy and have the cell body located distant from the lesion site may also atrophy or even die. ${ }^{24}$

Spinal cord pericytes have been defined based on their perivascular anatomical location covered by the vascular basal lamina. ${ }^{31}$ Classically, the pericytes in the blood vessel wall are in close contact with endothelial cells. ${ }^{32}$ Pericytes have long projections that surround the vessel along the length. Thus, pericytes may interact with other vascular components, both exerting physical contact and paracrine signaling. ${ }^{32}$ Their ratio to endothelial cells is approximately $1: 1,{ }^{33}$ indicating their tremendous relevance in the central nervous system physiopathology. In addition to blood vessel stabilization, pericytes contribute crucially to vascular 
maturation, development, remodeling, permeability, and blood flow control. ${ }^{34-36}$ Pericytes are also essential in the maintenance of functional integrity of the blood-spinal cord barrier. ${ }^{37-42}$ The ability of pericytes to work as stem cells, ${ }^{43}$ generating other cell types, has been described in the past 10 years.

Previous studies have found that a pericyte subpopulation also originates scar-producing cells after spinal cord injury. ${ }^{44,45}$ After spinal cord lesion, pericytes detach from the blood vessels, proliferate, and migrate to the center of the fibrous scar that is being formed, contributing to the lesion sealing. ${ }^{44-47}$ The authors of these studies used a mouse model of spinal cord injury combined with genetic tracking and depletion of a pericyte subset to study the role of pericytes during scarring. They generated a mouse model (GlastCreER/Rosa26-YFP) in which a pericyte subpopulation and all their progeny are genetically labeled with fluorescence based on their expression of the glutamate aspartate transporter (Glast). Glast-expressing pericytes contribute significantly to the fibrotic spinal cord scar formation after injury. On the basis of this knowledge, the group created another mouse model (Glast-CreER/KRas floxed, named
Glast-Rasless) in which the Glast-expressing pericytes lack KRas protein, essential for proliferation. Therefore, in these mice, pericyte proliferation is stopped after tamoxifen administration. After spinal cord dorsal hemisection, fibrotic scarring in Glast-Rasless mice is reduced. Moreover, Dias et $\mathrm{al}^{44}$ and Viana Magno et $\mathrm{al}^{48}$ examined the effect of blockage of Glast-expressing pericytes on other cell populations and found that, in Glast-Rasless mice, inflammation and astrogliosis also decreased. Strikingly, by using optogenetic analysis, ${ }^{44,48}$ they demonstrated that reduction of scarring in Glast-Rasless animals facilitates corticospinal tract axon regeneration and integration into the local neural circuitry (Figure 1). Importantly, axonal regeneration in the spinal cord resulted in motor performance improvement in Glast-Rasless mice. Notably, blocking pericyte scar formation after spinal cord injury resulted in modest increases in axon regeneration comparable to the effects of multiple other experimental treatments. Although this elegant study brings a novel concept to the field, the problem of how to efficiently regenerate the spinal cord after lesion remains unsolved. This work provides a novel cellular target to avoid scarring after spinal cord injury. Interestingly, another group demonstrated

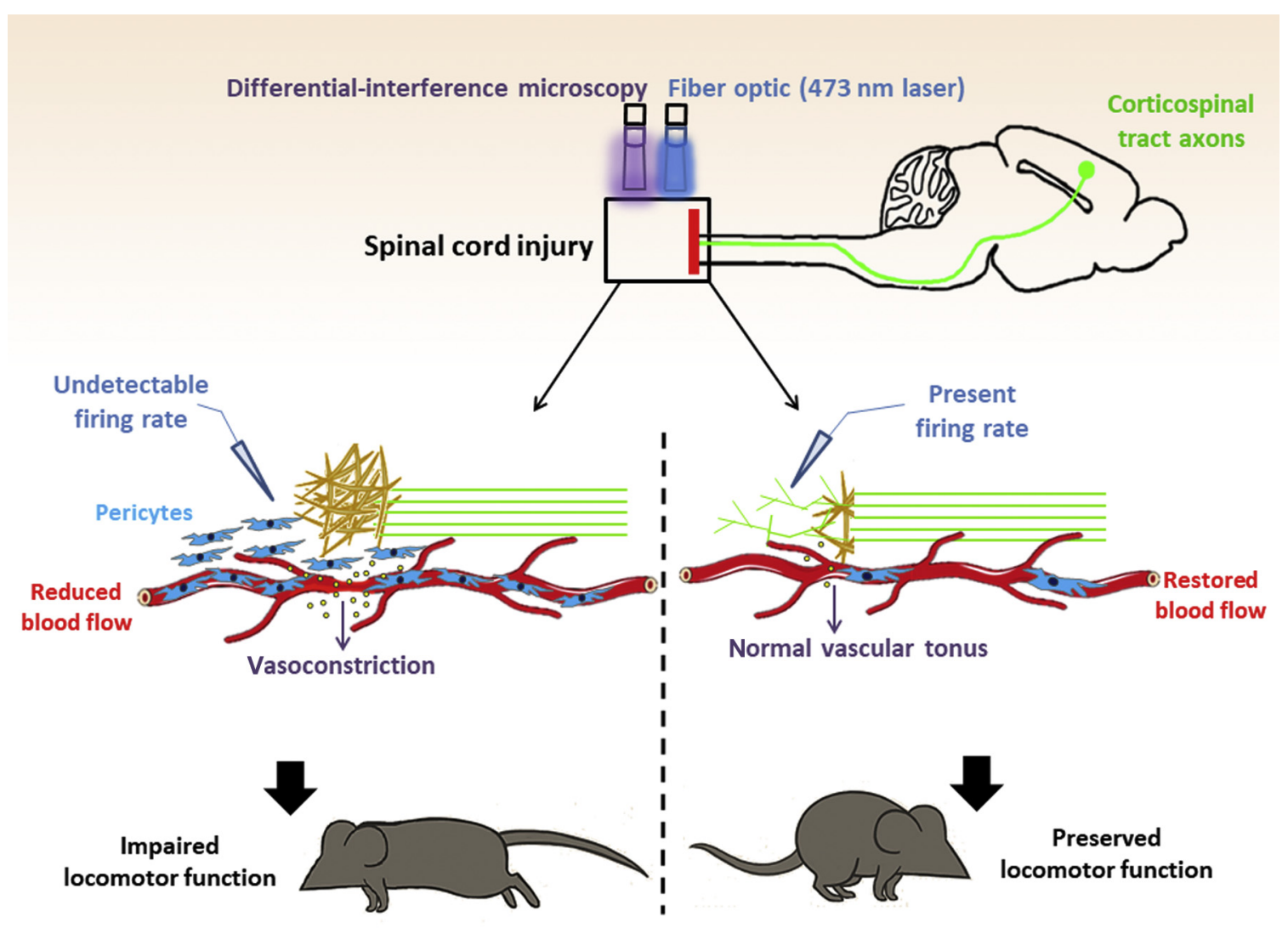

Figure 1 The role of pericytes in scarring in the injured spinal cord. Pericytes are present surrounding the spinal cord vasculature. The study by Dias et al ${ }^{44}$ now suggests a new function for pericytes after spinal cord injury. Blockage of a pericyte subset in the injured spinal cord microenvironment reduces fibrotic scar tissue formation, promotes axonal regeneration, and improves functional recovery. The authors used optogenetic stimulation to show that corticospinal tract axons were regenerated in animals with pericyte-derived scarring attenuation. 
that pericytes are also needed for the revascularization after spinal cord injury of the damaged area. ${ }^{49} \mathrm{We}$ discuss novel developments in pericyte biology in the spinal cord.

\section{Heterogeneity of Pericytes in the Spinal Cord}

Pericytes are not homogeneous in their morphology, distribution, molecular markers, origin, and function. ${ }^{31} \mathrm{~A}$ subpopulation of pericytes (Glast+) participates in the scarring after spinal cord injury. ${ }^{44}$ This subset of pericytes corresponds to approximately $10 \%$ of spinal cord pericytes. ${ }^{44}$ It remains unknown whether Glast-expressing pericytes differ from other spinal cord pericytes in their morphology, distribution, and origin. In the bone marrow, two distinct pericyte subtypes are present based on their attachment to arterioles or sinusoids. ${ }^{50}$ Future studies should explore whether Glast-expressing pericytes are associated with specific blood vessel type in the spinal cord. Pericytes from different organs differ in their embryonic origin. ${ }^{51}$ In most tissues, pericytes derive from the mesoderm. ${ }^{51}$ Lineage tracing experiments demonstrate that pericytes in the thymus and cephalic region derive from the neuroectoderm, ${ }^{52}$ whereas in the heart, lung, liver, and gut, they derive from the mesothelium. ${ }^{51,53}$ Interestingly, recent studies revealed that not all pericytes from the same organ have the same ancestry. ${ }^{31}$ For instance, in the embryonic skin, both pericytes from ectodermal and hematopoietic origin are found. ${ }^{54}$ Whether the spinal cord stores pericytes with distinct embryonic origins remains unknown. More importantly, whether Glast-expressing pericytes derive from a different source than the other spinal cord pericytes is still an open question.

The most used molecular markers that have been identified to label the pericyte population as a whole are nerve/glial antigen 2 (NG2) proteoglycan ${ }^{55}$ and platelet-derived growth factor receptor $\beta$ (PDGFR $\beta$ ) ${ }^{56}$ Unfortunately, however, there is no single marker that can be used to unequivocally label exclusively the whole population of pericytes. Pericyte heterogeneity is also observed based on their marker expression profiles. ATP-sensitive potassium inwardly rectifying channel Kir6.1 is highly expressed in cerebral pericytes but undetectable in pericytes from other tissues. ${ }^{57}$ Leptin receptor-expressing pericytes are distinct from the ones that do not express this receptor. ${ }^{53,58,59}$ Pericytes also vary on their expression of $\alpha$-smooth muscle actin protein and aminopeptidase $\mathrm{N}$ (CD13). ${ }^{60}$ Several other markers have been recently found to label pericyte subpopulations, such as Myh11, regulator of $\mathrm{G}$ protein signaling 5, desmin, vimentin, ATP-binding cassette, subfamily C, member 9, CD133, alkaline phosphatase, endosialin, Tbx18, CD146, vitronectin, interferon-induced transmembrane protein 1, and others. ${ }^{61-66}$ Nevertheless, it remains unknown whether spinal cord pericytes express those markers and what level of overlap is between Glast-expressing the pericytes, and any of these pericyte subpopulations. Two pericyte subpopulations were also described in the spinal cord based on NG2-DsRed and Nestin-GFP expression. Type 1 (NG2-DsRed ${ }^{+} /$Nestin$\left.G F P^{-}\right)$and type $2\left(N G 2-D s R e d^{+} / N e s t i n-G F P^{+}\right)$subsets were reported surrounding blood vessels in the spinal cord of transgenic NG2-DsRed/Nestin-GFP mice. ${ }^{47}$ Importantly, only type 1 pericytes are recruited to the center of the fibrous scar formed after spinal cord injury, suggesting that these correspond to Glast-expressing pericytes. ${ }^{47}$ Future studies should reveal a specific membrane marker to allow the isolation of cells equivalent to Glast-expressing pericytes from the human spinal cord.

Notably, although pericytes are defined based on their anatomical position and surrounding blood vessels, not all cells in this perivascular location are necessarily pericytes. ${ }^{67}$ In addition to pericytes, other cells have been described in this location around the vascular bed, including fibroblasts, ${ }^{19}$ macrophages, ${ }^{68,69}$ microglia, ${ }^{70}$ adventitial cells, ${ }^{71}$ and vascular smooth muscle cells. ${ }^{72}$ Altogether this brings the possibility that other Glast-expressing, nonpericytic cells may be involved in spinal cord scarring described by Dias et al. ${ }^{44}$ Therefore, it will be interesting to verify whether all Glast-expressing cells are located beneath the basal lamina that covers endothelial cells, which is a pericytic characteristic. The discovery of molecular markers specific to the other pericyte subpopulations possibly present in the spinal cord will help to reveal in the future their roles in the physiology and pathology of this organ.

\section{The Role of Pericytes after Spinal Cord Injury}

Blocking Glast-expressing pericytes after spinal cord injury improves axonal regeneration, and motor function. ${ }^{44}$ Nonetheless, the exact mechanistic reason why this happens remains unknown. The authors suggest that this is because of the reduction in lesion scarring, dependent of pericytes. Interestingly, another recent study suggests that blockage of pericytes after spinal cord injury may improve motor functions in the animal because of a decrease in local hypoxia. ${ }^{73} \mathrm{Li}$ et $\mathrm{al}^{73}$ used a rat model of spinal cord lesion combined with in vivo microscopy to show that pericytes regulate the capillary tone and blood flow in the spinal cord below the site of lesion after injury. This occurs as a consequence of aromatic L-amino acid decarboxylase enzyme overexpression within pericytes, which forms trace amines (tryptamine and tyramine), which in turn act via receptors on the pericytes themselves. These trace amines activate pericytes to locally constrict the vasculature, reducing blood flow and leading to spinal cord ischemia. Importantly, blocking these mechanisms in pericytes after spinal cord lesion decreases hypoxia, and ameliorates motor function and locomotion of injured animals. Nevertheless, it remains unknown whether the vasoconstriction that occurs after spinal cord injury is caused by a subgroup of pericytes and whether these include Glastexpressing pericytes. $\mathrm{Li}$ et $\mathrm{al}^{73}$ consider spinal cord pericytes as a homogeneous cell population in their study. Although 
most of spinal cord pericytes express the well-established markers NG2, PDGFR $\beta$, and $\mathrm{CD} 13,{ }^{45}$ the expression of multiple other molecular markers is heterogeneous; and different pericyte subpopulations were characterized in the spinal cord. For instance, the presence of two pericyte subtypes [type 1 (Nestin-GFP ING2-DsRed $^{+}$) and type 2 (Nestin-GFP $\left.\left.P^{+} / N G 2-D s R e d^{+}\right)\right]$was reported surrounding blood vessels in the spinal cord of bigenic Nestin-GFP/NG2-DsRed mice. ${ }^{47} \mathrm{Li}$ et al ${ }^{73}$ used NG2 and CD31 to identify the pericytes in the spinal cord, what does not distinguish pericyte subsets. Thus, whether only a fraction of pericytes promotes blood vessel constriction after spinal cord injury remains unknown. Future studies should explore whether this vasoconstriction inhibition also happens in Glast-Rasless mice. This exploration will reveal whether Glast-expressing pericytes are also essential for the hypoxia after spinal cord trauma and whether the improvement of motor functions in Glast-Rasless mice is exclusively because of blockage in fibrous scar production.

Spinal cord lesion also leads to neuropathic pain, which develops in approximately four-fifths of the injured patients, characterized by spontaneous pain, allodynia, and hyperalgesia. ${ }^{74}$ Despite advances in our understanding of the molecular and cellular changes involved in the neuropathic pain after spinal cord injury, the knowledge on the role of pericytes in this condition remains limited. Importantly, injury-induced neuropathic pain is accompanied by a pericyte loss. ${ }^{75}$ How and whether Glast-expressing pericytes are involved in the neuropathic pain remains to be discovered.

Pericytes have been suggested to also play important roles during inflammation. ${ }^{76}$ For instance, pericytes regulate lymphocyte activation ${ }^{77}$; overexpress essential adhesion molecules, such as vascular cell adhesion molecule 1 and intercellular adhesion molecule 1 , involved in the control of immune cell trafficking across the vasculature ${ }^{78}$; secrete a big repertoire of chemokines ${ }^{50}$; attract innate leukocytes that exit through the sprouting vessels ${ }^{79}$; contribute to the clearance of toxic cellular byproducts; and have direct phagocytic activity. ${ }^{80}$ Because neuroinflammation is implicated in the spinal cord lesion-induced neuropathic pain as an underlying mechanism, ${ }^{81}$ the better understanding of the crosstalk between pericytes and immune cell populations involved in the neuropathic pain will foster the development of novel treatments to maintain spinal cord homeostasis after trauma.

Spinal cord regeneration after injury needs either neurons to survive in the damaged cord and initiate new axonal growth, establishing new synaptic contacts, or neurogenesis. ${ }^{82,83}$ The main obstacles for spinal cord repair are the diminished capacity to regrow the adult neurons and the presence of the fibrous scar at the lesion. ${ }^{84}$ An ideal therapy for spinal cord lesion would be to eliminate the two obstacles. Dias et $\mathrm{al}^{44}$ describe that Glast-expressing pericytes contribute to the scar formation (Figure 2). Thus, in blocking those we are removing one of the obstacles. Importantly, pericytes have the capacity to behave as progenitors, ${ }^{62}$ forming neural cells in vitro. ${ }^{61,85,86}$ Whether pericytes have this capacity also in vivo after spinal cord injury remains completely unknown and should be explored in future studies. Importantly, neurogenesis in the adult central nervous system produce interneurons that improve

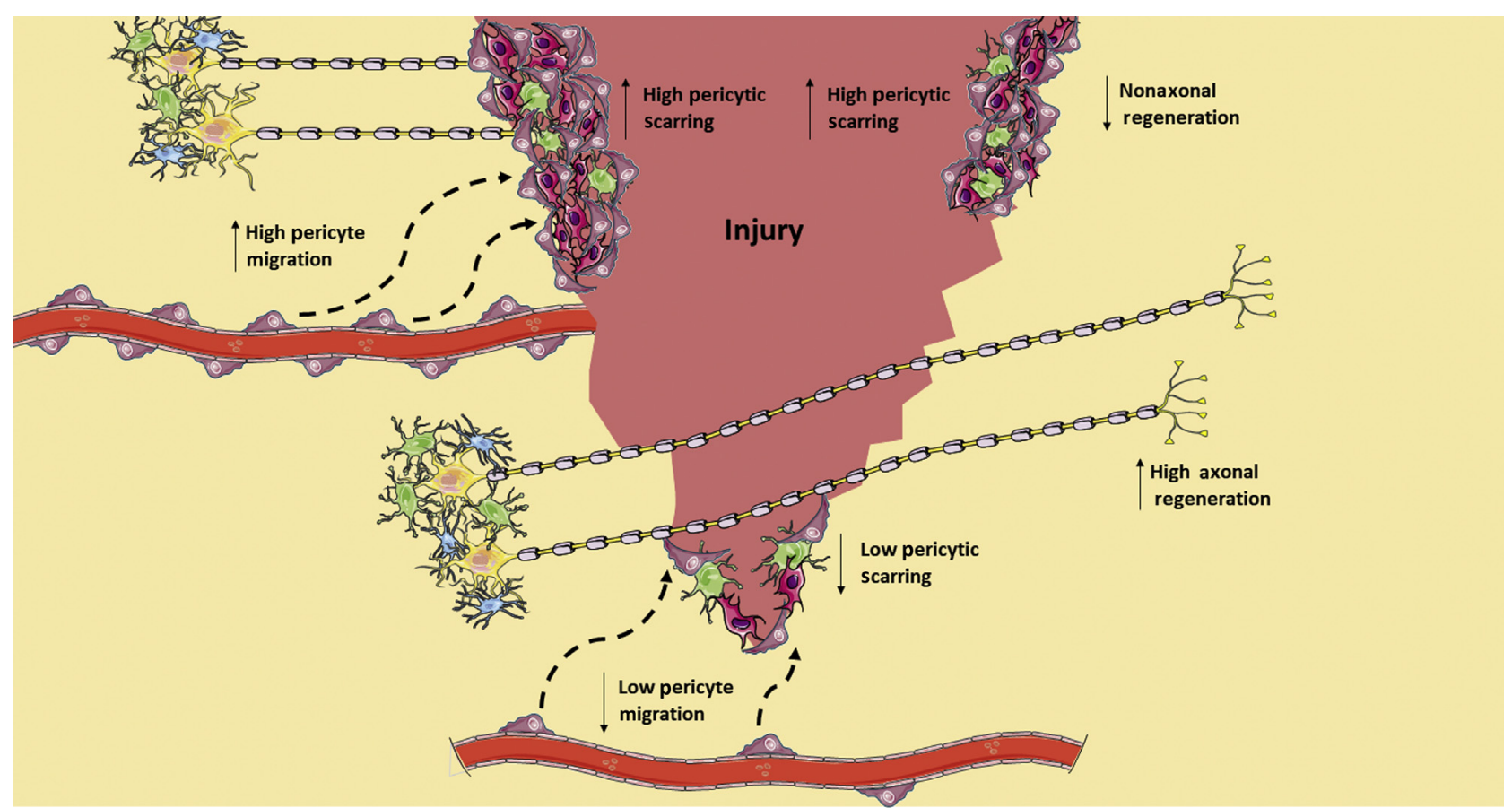

Figure 2 Pericytes contribute to the scar formation that inhibits neuronal regeneration. The reduction of pericytic activation attenuates fibrotic tissue formation, facilitating serotonergic and corticospinal axonal regeneration and improving sensorimotor functionality. 
local connectivity. ${ }^{43}$ Whether neurogenesis can replace long mature neurons to restore function after spinal cord injury remains unanswered. In addition, whether pericytes could be used as a source for local interneurons to try to reconnect unaffected neurons should be explored in future works. Interestingly, the neurogenic pericytes in vitro are the ones that do not participate in the scar formation after spinal cord injury, ${ }^{47,61}$ whereas the ones that form fibrous tissue-producing cells do not form neural cells in vitro.

After spinal cord injury, severe demyelination, destruction of myelin-supporting cells, also happens, disrupting signal propagation ${ }^{87}$ Myelin formation is delayed during remyelination in the central nervous system of pericytes-deficient mice, ${ }^{88}$ suggesting that pericytes are important for remyelination. Future studies should examine the association between the pericyte population important for remyelination and Glast-expressing pericytes. If by blocking scar formation remyelination is blocked, a selective way to block scar formation without affecting remyelination after spinal cord injury needs to be identified.

The roles of pericyte subpopulations in the spinal cord microenvironment still remain largely unexplored. Recently, it was demonstrated that pericytes interact actively with distinct immune cells and display multiple immune properties. ${ }^{76}$ For instance, pericytes secrete a big repertoire of chemokines essential for immune cell functions ${ }^{50,89}$ and express adhesion molecules involved in the control of immune cell trafficking via the vascular bed, such as vascular cell adhesion molecule 1and intercellular adhesion molecule $1 .^{78}$ Overall, pericyte functions are complex, and our knowledge about the crosstalk between pericytes and immune cells in the spinal cord microenvironment are still limited. Thus, the cross-talk between distinct immune cell subpopulations present in the spinal cord after injury with the different pericytes subsets remains to be examined. Further studies are required to evaluate the importance of pericytes' interactions with immune cells during spinal cord repair.

\section{Cross-Talk between Astrocytes and Pericytes after Spinal Cord Injury}

Spinal cord lesion triggers the activation and recruitment of various cell types, including immune cells and astrocytes. The astrocytic component in the scar has been the subject of intensive research, and only recently the focus changed to pericytes. In the first weeks after spinal cord injury, astrocytes proliferate, migrate, intertwine their processes, and assemble around the edges of the damaged region. ${ }^{90}$ The association between astrocytes and pericytes during spinal cord healing remains poorly understood. Importantly, the exact contribution of astrocytes and pericytes to the scar remains unknown. The use of a Glast promoter-based tracking mouse model to label and trace pericytes leaves several open questions because Glast is also expressed in other cellular populations, especially in astrocytes. ${ }^{91}$ To assess unequivocally the contribution of pericytes versus astrocytes to the scar, future studies should perform tracking and fate mapping experiments using novel genetic mouse models specific to pericytes or astrocytes.

\section{Pericytes as the Origin of Fibrous Tissue}

Deposition of extracellular matrix proteins after injury is beneficial for repair in the short term. ${ }^{92}$ Nevertheless, during a prolonged period, fibrous tissue formation, characterized by excessive connective tissue, becomes detrimental, leading to loss of tissue architecture and organ failure. ${ }^{93}$ Fibrous tissue deposition can be triggered in response to various insults, such as injury, chronic inflammation, and autoimmune reactions. It occurs in a wide range of tissues, becoming irreversible over time and leading to organ failure. ${ }^{47,94}$ Although a decrease in fibrous tissue formation may probably protect organs, therapies available are still very limited.

Comprehending which cells generate the fibrous tissue may allow us to gain control or even reverse fibrous tissue deposition in pathologic conditions, and recent studies in several organs will accelerate the design of targeted antifibrotic therapies. So far, multiple cell populations have been implicated as the origin of fibrous tissue-producing cells, including epithelial cells, ${ }^{95}$ endothelial cells, ${ }^{96}$ circulating progenitor cells, ${ }^{97}$ and resident fibroblasts ${ }^{98}$ (Figure 3). During the last few years, a number of studies have improved our knowledge of the participation of pericytes in the fibrotic tissue formation in several organs. ${ }^{99-101}$ Dias et $\mathrm{al}^{44}$ reveal the participation of Glast-expressing pericytes in fibrous tissue deposition after spinal cord injury. Future studies should examine whether Glast-expressing pericytes are present in other organs and whether they are the main source for fibrous tissue-producing cells. Recently, Glil-expressing perivascular cells have been implicated as essential for injury-induced fibrosis in several organs. ${ }^{102}$ It remains unknown what is the overlap between Glast-expressing and Gli1-expressing pericytes. Are Gli1expressing pericytes present in the spinal cord? If yes, what is their role?

\section{Clinical Relevance}

Dias et $\mathrm{al}^{44}$ report that complete blockage of fibrotic scar formation by high recombination efficiency in Glast-Rasless mice leads to failure in the axonal regeneration, suggesting that pericytes should not be completely arrested. This finding may be attributable to the necessity of the lesion closure for nerve repair. Future studies should reveal the mechanistic details of this phenomenon. In addition, when translating their findings into humans, this should be taken into consideration. Therefore, approaches to target Glastexpressing pericytes without interception in the injury site closing should be developed. Potential molecular targets expressed by pericytes have been proposed, for instance, 


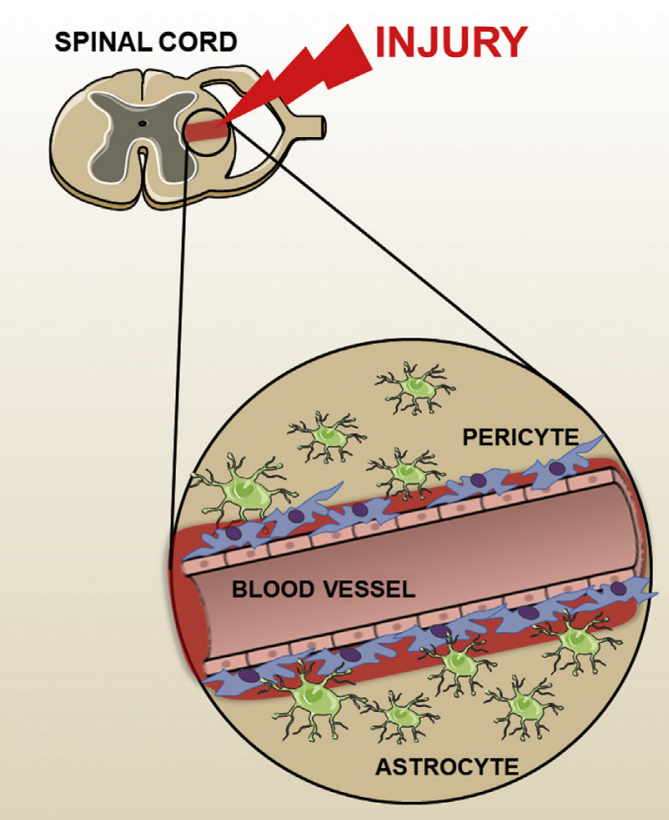

\section{FIBROTIC TISSUE FORMATION IN SEVERAL ORGANS}

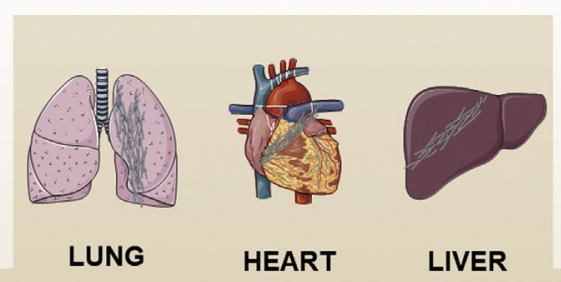

FIBROUS TISSUE-PRODUCING CELLS
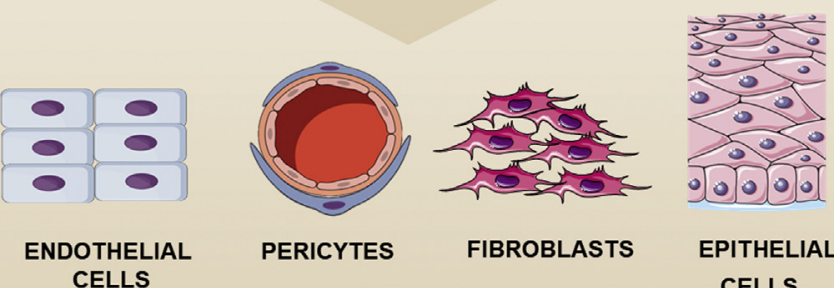

PERICYTES

FIBROBLASTS

EPITHELIAL

CELLS

Figure 3 Multiple cell populations have been implicated as the origin of fibrous tissue-producing cells. Deposition of extracellular matrix proteins occurs, after injury, during a prolonged period. The fibrous tissue formation, characterized by excessive connective tissue, becomes detrimental, leading to the loss of tissue architecture and organ failure. Multiple cell populations have been implicated as the origin of fibrous tissue-producing cells, including pericytes, endothelial cells, epithelial cells, and resident fibroblasts.

PDGFR $\beta$. Receptor tyrosine kinase inhibitors that target PDGFR $\beta$, up-regulated in pericytes, such as sunitinib and imatinib, have been tested, ${ }^{103}$ and clinical trials using drugs that target pericytes are under way for multiple conditions, such as cancer treatment. ${ }^{104}$ Because the experimental data do not always predict success in humans, gene expression analysis of human pericytes from different stages after spinal cord injury will reveal new potential molecular targets.

Interestingly, moderate inhibition of pericyte generation provided the best results in spinal cord injury recovery. Importantly, after complete inhibition, the animals had worse outcomes. ${ }^{44}$ Previous studies ${ }^{44,45}$ used two groups of mice, vehicle treated and tamoxifen treated, to induce recombination of the labeled subset of Glastpositive pericytes. Nevertheless, the tamoxifen-treated group was split into two groups: one in which the animals exhibited high recombination efficiency and failure to seal off the injury site, defined as Tam-def animals, and the other in which animals had intermediate levels of recombination and the lesion site was able to close, defined as Tam animals. By stratifying the experimental animals into mediumand high-recombination subgroups, the study outlined the beneficial effects in the medium recombination group. It is only in the Tam animal group that corticospinal tract axonal regeneration is observed. Strikingly, the total inhibition of pericytes did not improve the recovery after lesion. This reveals that pericyte participation in spinal cord healing is more complex than previously thought. It also opens the possibility that subsets within the population of Glastpositive pericytes may exist. Future studies are required to confirm these findings and to translate this into therapeutic use.

The technique to induce spinal cord injury may influence and trigger different biological processes in the animals. There is appreciable diversity in the approaches used to create the dorsal column lesion, such as contusion, crush, and transection. Moreover, there is variability within each method, depending on the depth of the lesion, anatomical level, type of instruments used, force applied, species, and age of animals. Therefore, the severity of the functional defect will depend on the exact lesion technique and the extent of the final lesion. Dias et a ${ }^{44}$ performed the hemisection at the midthoracic level at the dorsal funiculus to a depth of $0.8 \mathrm{~mm}$. Although specific hemisection of the dorsal column is rarely seen in human spinal cord injury, these lesions enable us to explore the mechanistic details regarding the remodeling, sprouting, and die back at the axonal level. ${ }^{105}$ Spinal cord studies using rodent models, although trying to recreate features of human spinal cord lesion as closely as possible, may not be translatable to humans. ${ }^{106}$ No one model can encompass all aspects of the spinal cord trauma. Therefore, the precise knowledge of human spinal cord injury biology will come from the combination of distinct models. Humans are large compared 
with mice, with a spinal cord that is longer by more than an order of magnitude. Consequently, clinical improvement, including motor recovery, which needs long distance axonal regeneration for humans, cannot be directly analyzed in the mouse models. Accordingly, experimental findings from rodent models that report improvement in locomotion and axonal regrowth may misinform us because the volumes of gray matter that require reinnervation are much larger in humans than in mice. Furthermore, human recovery after spinal cord lesion is slower than in mice. It will be important to recognize whether cells equivalent to Glast-expressing pericytes are also present in the human spinal cord and whether their role is the same as in mice after spinal cord injury. The degree of pericyte-dependent scarring in patients with spinal cord lesion also might vary, depending on the severity and level of the injury. It will be interesting to explore whether pericytes play a distinct role in paraplegics versus tetraplegics.

\section{Conclusion}

Recent studies reveal Glast-expressing pericytes as an important novel target in the spinal cord microenvironment after trauma. However, our understanding of pericytes biology in the spinal cord microenvironment still remains limited. The exact role of non-Glast-expressing pericytes after spinal cord injury is yet completely unknown. Future studies should shed light on the complexity and interactions between pericytes and other cellular components of the spinal cord microenvironment after injury. A great challenge for the future will be to translate experimental data into humans. Improving the availability of human spinal cord samples will be essential to reach this goal.

\section{References}

1. Almeida VM, Paiva AE, Sena IFG, Mintz A, Magno LAV, Birbrair A: Pericytes make spinal cord breathless after injury. Neuroscientist 2018, 24:440-447

2. Wyndaele M, Wyndaele JJ: Incidence, prevalence and epidemiology of spinal cord injury: what learns a worldwide literature survey? Spinal Cord 2006, 44:523-529

3. New PW, Sundararajan V: Incidence of non-traumatic spinal cord injury in Victoria, Australia: a population-based study and literature review. Spinal Cord 2008, 46:406-411

4. Boschen KA, Tonack M, Gargaro J: Long-term adjustment and community reintegration following spinal cord injury. Int J Rehabil Res 2003, 26:157-164

5. Cristante AF, Barros Filho TE, Marcon RM, Letaif OB, Rocha ID: Therapeutic approaches for spinal cord injury. Clinics 2012, 67: $1219-1224$

6. Hooshmand MJ, Galvan MD, Partida E, Anderson AJ: Characterization of recovery, repair, and inflammatory processes following contusion spinal cord injury in old female rats: is age a limitation? Immun Ageing 2014, 11:15

7. Sinescu C, Popa F, Grigorean VT, Onose G, Sandu AM, Popescu M, Burnei G, Strambu V, Popa C: Molecular basis of vascular events following spinal cord injury. J Med Life 2010, 3:254-261
8. Wright KT, El Masri W, Osman A, Chowdhury J, Johnson WE: Concise review: bone marrow for the treatment of spinal cord injury: mechanisms and clinical applications. Stem Cells 2011, 29:169-178

9. Burda JE, Sofroniew MV: Reactive gliosis and the multicellular response to CNS damage and disease. Neuron 2014, 81:229-248

10. Beck KD, Nguyen HX, Galvan MD, Salazar DL, Woodruff TM, Anderson AJ: Quantitative analysis of cellular inflammation after traumatic spinal cord injury: evidence for a multiphasic inflammatory response in the acute to chronic environment. Brain 2010, 133:433-447

11. Fitch MT, Doller C, Combs CK, Landreth GE, Silver J: Cellular and molecular mechanisms of glial scarring and progressive cavitation: in vivo and in vitro analysis of inflammation-induced secondary injury after CNS trauma. J Neurosci 1999, 19:8182-8198

12. Buss A, Pech K, Kakulas BA, Martin D, Schoenen J, Noth J, Brook GA: Growth-modulating molecules are associated with invading Schwann cells and not astrocytes in human traumatic spinal cord injury. Brain 2007, 130:940-953

13. Decimo I, Bifari F, Rodriguez FJ, Malpeli G, Dolci S, Lavarini V, Pretto S, Vasquez S, Sciancalepore M, Montalbano A, Berton V, Krampera M, Fumagalli G: Nestin- and doublecortin-positive cells reside in adult spinal cord meninges and participate in injury-induced parenchymal reaction. Stem Cells 2011, 29:2062-2076

14. Cregg JM, DePaul MA, Filous AR, Lang BT, Tran A, Silver J: Functional regeneration beyond the glial scar. Exp Neurol 2014, 253: 197-207

15. Faulkner JR, Herrmann JE, Woo MJ, Tansey KE, Doan NB, Sofroniew MV: Reactive astrocytes protect tissue and preserve function after spinal cord injury. J Neurosci 2004, 24:2143-2155

16. Silver J, Miller JH: Regeneration beyond the glial scar. Nat Rev Neurosci 2004, 5:146-156

17. Silver J, Schwab ME, Popovich PG: Central nervous system regenerative failure: role of oligodendrocytes, astrocytes, and microglia. Cold Spring Harbor Perspect Biol 2014, 7:a020602

18. Rolls A, Shechter R, London A, Segev Y, Jacob-Hirsch J, Amariglio N, Rechavi G, Schwartz M: Two faces of chondroitin sulfate proteoglycan in spinal cord repair: a role in microglia/macrophage activation. PLoS Med 2008, 5:e171

19. Soderblom C, Luo X, Blumenthal E, Bray E, Lyapichev K, Ramos J, Krishnan V, Lai-Hsu C, Park KK, Tsoulfas P, Lee JK: Perivascular fibroblasts form the fibrotic scar after contusive spinal cord injury. J Neurosci 2013, 33:13882-13887

20. Hara M, Kobayakawa K, Ohkawa Y, Kumamaru H, Yokota K Saito T, Kijima K, Yoshizaki S, Harimaya K, Nakashima Y, Okada S: Interaction of reactive astrocytes with type I collagen induces astrocytic scar formation through the integrin- $\mathrm{N}$-cadherin pathway after spinal cord injury. Nat Med 2017, 23:818-828

21. Windle WF, Clemente CD, Chambers WW: Inhibition of formation of a glial barrier as a means of permitting a peripheral nerve to grow into the brain. J Comp Neurol 1952, 96:359-369

22. Windle WF: Regeneration of axons in the vertebrate central nervous system. Physiol Rev 1956, 36:427-440

23. Sofroniew MV: Astrocyte barriers to neurotoxic inflammation. Nat Rev Neurosci 2015, 16:249-263

24. Anderson MA, Burda JE, Ren Y, Ao Y, O'Shea TM, Kawaguchi R, Coppola G, Khakh BS, Deming TJ, Sofroniew MV: Astrocyte scar formation aids central nervous system axon regeneration. Nature 2016, 532:195-200

25. Yu X, Bellamkonda RV: Dorsal root ganglia neurite extension is inhibited by mechanical and chondroitin sulfate-rich interfaces. J Neurosci Res 2001, 66:303-310

26. Tom VJ, Kadakia R, Santi L, Houle JD: Administration of chondroitinase $\mathrm{ABC}$ rostral or caudal to a spinal cord injury site promotes anatomical but not functional plasticity. J Neurotrauma 2009, 26 : $2323-2333$

27. Li S, Strittmatter SM: Delayed systemic Nogo-66 receptor antagonist promotes recovery from spinal cord injury. J Neurosci 2003, 23 : 4219-4227 
28. Schnell L, Hunanyan AS, Bowers WJ, Horner PJ, Federoff HJ, Gullo M, Schwab ME, Mendell LM, Arvanian VL: Combined delivery of Nogo-A antibody, neurotrophin-3 and the NMDA-NR2d subunit establishes a functional 'detour' in the hemisected spinal cord. Eur J Neurosci 2011, 34:1256-1267

29. Wu BQ, Bi ZG, Qi Q: Inactivation of the Rho-ROCK signaling pathway to promote neurologic recovery after spinal cord injuries in rats. Chin Med J 2013, 126:3723-3727

30. Coll-Miro M, Francos-Quijorna I, Santos-Nogueira E, TorresEspin A, Bufler P, Dinarello CA, Lopez-Vales R: Beneficial effects of IL-37 after spinal cord injury in mice. Proc Natl Acad Sci U S A 2016, 113:1411-1416

31. Dias Moura Prazeres PH, Sena IFG, Borges IDT, de Azevedo PO, Andreotti JP, de Paiva AE, de Almeida VM, de Paula Guerra DA, Pinheiro Dos Santos GS, Mintz A, Delbono O, Birbrair A: Pericytes are heterogeneous in their origin within the same tissue. Dev Biol 2017, 427:6-11

32. Sa-Pereira I, Brites D, Brito MA: Neurovascular unit: a focus on pericytes. Mol Neurobiol 2012, 45:327-347

33. Shepro D, Morel NM: Pericyte physiology. FASEB J 1993, 7: $1031-1038$

34. Enge M, Bjarnegard M, Gerhardt H, Gustafsson E, Kalen M, Asker N, Hammes HP, Shani M, Fassler R, Betsholtz C: Endothelium-specific platelet-derived growth factor-B ablation mimics diabetic retinopathy. EMBO J 2002, 21:4307-4316

35. Hellstrom M, Gerhardt H, Kalen M, Li X, Eriksson U, Wolburg H, Betsholtz C: Lack of pericytes leads to endothelial hyperplasia and abnormal vascular morphogenesis. J Cell Biol 2001, 153:543-553

36. Pallone TL, Zhang Z, Rhinehart K: Physiology of the renal medullary microcirculation. Am J Physiol Renal Physiol 2003, 284:F253-F266

37. Krueger M, Bechmann I: CNS pericytes: concepts, misconceptions, and a way out. Glia 2010, 58:1-10

38. Armulik A, Genove G, Mae M, Nisancioglu MH, Wallgard E, Niaudet C, He L, Norlin J, Lindblom P, Strittmatter K, Johansson BR, Betsholtz C: Pericytes regulate the blood-brain barrier. Nature 2010, 468:557-561

39. Bell RD, Winkler EA, Sagare AP, Singh I, LaRue B, Deane R, Zlokovic BV: Pericytes control key neurovascular functions and neuronal phenotype in the adult brain and during brain aging. Neuron 2010, 68:409-427

40. Thanabalasundaram G, Schneidewind J, Pieper C, Galla HJ: The impact of pericytes on the blood-brain barrier integrity depends critically on the pericyte differentiation stage. Int J Biochem Cell Biol 2011, 43:1284-1293

41. Kamouchi M, Ago T, Kitazono T: Brain pericytes: emerging concepts and functional roles in brain homeostasis. Cell Mol Neurobiol 2011, 31:175-193

42. Daneman R, Zhou L, Kebede AA, Barres BA: Pericytes are required for blood-brain barrier integrity during embryogenesis. Nature 2010, 468:562-566

43. Andreotti JP, Silva WN, Costa AC, Picoli CC, Bitencourt FCO, Coimbra-Campos LMC, Resende RR, Magno LAV, RomanoSilva MA, Mintz A, Birbrair A: Neural stem cell niche heterogeneity. Semin Cell Dev Biol 2019, [Epub ahead of print] doi:10.1016/j. semcdb.2019.01.005

44. Dias DO, Kim H, Holl D, Werne Solnestam B, Lundeberg J, Carlen M, Goritz C, Frisen J: Reducing pericyte-derived scarring promotes recovery after spinal cord injury. Cell 2018, 173: $153-65 \mathrm{e} 22$

45. Goritz C, Dias DO, Tomilin N, Barbacid M, Shupliakov O, Frisen J: A pericyte origin of spinal cord scar tissue. Science 2011, 333: $238-242$

46. Matsushita T, Lankford KL, Arroyo EJ, Sasaki M, Neyazi M, Radtke C, Kocsis JD: Diffuse and persistent blood-spinal cord barrier disruption after contusive spinal cord injury rapidly recovers following intravenous infusion of bone marrow mesenchymal stem cells. Exp Neurol 2015, 267:152-164
47. Birbrair A, Zhang T, Files DC, Mannava S, Smith T, Wang ZM, Messi ML, Mintz A, Delbono O: Type-1 pericytes accumulate after tissue injury and produce collagen in an organ-dependent manner. Stem Cell Res Ther 2014, 5:122

48. Viana Magno LA, Tenza-Ferrer H, Collodetti M, Felipe Guimaraes Aguiar M, Paula Carneiro Rodrigues A, Souza da Silva R, do Prado Silva J, Ferreira Nicolau N, Valadao Freitas Rosa D, Birbrair A, Marques Miranda D, Aurelio Romano-Silva M: Optogenetic stimulation of the M2 cortex reverts motor dysfunction in a mouse model of Parkinson's Disease. J Neurosci 2019, 39:3234-3248

49. Hesp ZC, Yoseph RY, Suzuki R, Jukkola P, Wilson C, Nishiyama A, McTigue DM: Proliferating NG2-cell-dependent angiogenesis and scar formation alter axon growth and functional recovery after spinal cord injury in mice. J Neurosci 2018, 38:1366-1382

50. Asada N, Kunisaki Y, Pierce H, Wang Z, Fernandez NF, Birbrair A, Ma'ayan A, Frenette PS: Differential cytokine contributions of perivascular haematopoietic stem cell niches. Nat Cell Biol 2017, 19: 214-223

51. Armulik A, Genove G, Betsholtz C: Pericytes: developmental, physiological, and pathological perspectives, problems, and promises. Dev Cell 2011, 21:193-215

52. Trost A, Lange S, Schroedl F, Bruckner D, Motloch KA, Bogner B, Kaser-Eichberger A, Strohmaier C, Runge C, Aigner L, Rivera FJ, Reitsamer HA: Brain and retinal pericytes: origin, function and role. Front Cell Neurosci 2016, 10:20

53. Khan JA, Mendelson A, Kunisaki Y, Birbrair A, Kou Y, ArnalEstape A, Pinho S, Ciero P, Nakahara F, Ma'ayan A, Bergman A, Merad M, Frenette PS: Fetal liver hematopoietic stem cell niches associate with portal vessels. Science 2016, 351:176-180

54. Yamazaki T, Nalbandian A, Uchida Y, Li W, Arnold TD, Kubota Y, Yamamoto S, Ema M, Mukouyama YS: Tissue myeloid progenitors differentiate into pericytes through tgf-beta signaling in developing skin vasculature. Cell Rep 2017, 18:2991-3004

55. Ozerdem U, Grako KA, Dahlin-Huppe K, Monosov E, Stallcup WB: NG2 proteoglycan is expressed exclusively by mural cells during vascular morphogenesis. Dev Dyn 2001, 222:218-227

56. Winkler EA, Bell RD, Zlokovic BV: Pericyte-specific expression of PDGF beta receptor in mouse models with normal and deficient PDGF beta receptor signaling. Mol Neurodegener 2010, 5:32

57. Bondjers C, He L, Takemoto M, Norlin J, Asker N, Hellstrom M, Lindahl P, Betsholtz C: Microarray analysis of blood microvessels from PDGF-B and PDGF-Rbeta mutant mice identifies novel markers for brain pericytes. FASEB J 2006, 20:1703-1705

58. Birbrair A, Frenette PS: Niche heterogeneity in the bone marrow. Ann N Y Acad Sci 2016, 1370:82-96

59. Kunisaki Y, Bruns I, Scheiermann C, Ahmed J, Pinho S, Zhang D, Mizoguchi T, Wei Q, Lucas D, Ito K, Mar JC, Bergman A, Frenette PS: Arteriolar niches maintain haematopoietic stem cell quiescence. Nature 2013, 502:637-643

60. Morikawa S, Baluk P, Kaidoh T, Haskell A, Jain RK, McDonald DM: Abnormalities in pericytes on blood vessels and endothelial sprouts in tumors. Am J Pathol 2002, 160:985-1000

61. Birbrair A, Zhang T, Wang ZM, Messi ML, Enikolopov GN, Mintz A, Delbono O: Skeletal muscle pericyte subtypes differ in their differentiation potential. Stem Cell Res 2013, 10:67-84

62. Birbrair A, Borges IDT, Gilson Sena IF, Almeida GG, da Silva Meirelles L, Goncalves R, Mintz A, Delbono O: How plastic are pericytes? Stem Cells Dev 2017, 26:1013-1019

63. He L, Vanlandewijck M, Raschperger E, Andaloussi Mae M, Jung B, Lebouvier T, Ando K, Hofmann J, Keller A, Betsholtz C: Analysis of the brain mural cell transcriptome. Sci Rep 2016, 6:35108

64. Lousado L, Prazeres P, Andreotti JP, Paiva AE, Azevedo PO, Santos GSP, Filev R, Mintz A, Birbrair A: Schwann cell precursors as a source for adrenal gland chromaffin cells. Cell Death Dis 2017, 8:e3072

65. Silva WN, Leonel C, Prazeres PHDM, Sena IFG, Guerra DAP, Diniz IMA, Fortuna V, Mintz A, Birbrair A: Role of Schwann cells in cutaneous wound healing. Wound Repair Regen 2018, 26:392-397 
66. Pereira LX, Viana CTR, Orellano LAA, Almeida SA, Vasconcelos AC, Goes AM, Birbrair A, Andrade SP, Campos PP: Synthetic matrix of polyether-polyurethane as a biological platform for pancreatic regeneration. Life Sci 2017, 176:67-74

67. Prazeres P, Turquetti AOM, Azevedo PO, Barreto RSN, Miglino MA, Mintz A, Delbono O, Birbrair A: Perivascular cell alphav integrins as a target to treat skeletal muscle fibrosis. Int $\mathrm{J}$ Biochem Cell Biol 2018, 99:109-113

68. Bechmann I, Priller J, Kovac A, Bontert M, Wehner T, Klett FF, Bohsung J, Stuschke M, Dirnagl U, Nitsch R: Immune surveillance of mouse brain perivascular spaces by blood-borne macrophages. Eur J Neurosci 2001, 14:1651-1658

69. Silva WN, Prazeres P, Paiva AE, Lousado L, Turquetti AOM, Barreto RSN, de Alvarenga EC, Miglino MA, Goncalves R, Mintz A, Birbrair A: Macrophage-derived GPNMB accelerates skin healing. Exp Dermatol 2018, 27:630-635

70. Guillemin GJ, Brew BJ: Microglia, macrophages, perivascular macrophages, and pericytes: a review of function and identification. J Leukoc Biol 2004, 75:388-397

71. Crisan M, Corselli M, Chen WC, Peault B: Perivascular cells for regenerative medicine. J Cell Mol Med 2012, 16:2851-2860

72. Wanjare M, Kusuma S, Gerecht S: Perivascular cells in blood vessel regeneration. Biotechnol J 2013, 8:434-447

73. Li Y, Lucas-Osma AM, Black S, Bandet MV, Stephens MJ, Vavrek R, Sanelli L, Fenrich KK, Di Narzo AF, Dracheva S, Winship IR, Fouad K, Bennett DJ: Pericytes impair capillary blood flow and motor function after chronic spinal cord injury. Nat Med 2017, 23:733-741

74. Warms CA, Turner JA, Marshall HM, Cardenas DD: Treatments for chronic pain associated with spinal cord injuries: many are tried, few are helpful. Clin J Pain 2002, 18:154-163

75. Sauer RS, Kirchner J, Yang S, Hu L, Leinders M, Sommer C, Brack A, Rittner HL: Blood-spinal cord barrier breakdown and pericyte deficiency in peripheral neuropathy. Ann N Y Acad Sci 2017, 1405:71-88

76. Stark K, Pekayvaz K, Massberg S: Role of pericytes in vascular immunosurveillance. Front Biosci 2018, 23:767-781

77. Tu Z, Li Y, Smith DS, Sheibani N, Huang S, Kern T, Lin F: Retinal pericytes inhibit activated $\mathrm{T}$ cell proliferation. Invest Ophthalmol Vis Sci 2011, 52:9005-9010

78. Guijarro-Munoz I, Compte M, Alvarez-Cienfuegos A, AlvarezVallina L, Sanz L: Lipopolysaccharide activates Toll-like receptor 4 (TLR4)-mediated NF-kappaB signaling pathway and proinflammatory response in human pericytes. J Biol Chem 2014, 289: $2457-2468$

79. Stark K, Eckart A, Haidari S, Tirniceriu A, Lorenz M, von Bruhl ML, Gartner F, Khandoga AG, Legate KR, Pless R, Hepper I, Lauber K, Walzog B, Massberg S: Capillary and arteriolar pericytes attract innate leukocytes exiting through venules and 'instruct' them with pattern-recognition and motility programs. Nat Immunol 2013, 14: $41-51$

80. Castejon OJ: Ultrastructural pathology of cortical capillary pericytes in human traumatic brain oedema. Folia Neuropathol 2011, 49: $162-173$

81. Detloff MR, Fisher LC, McGaughy V, Longbrake EE, Popovich PG, Basso DM: Remote activation of microglia and proinflammatory cytokines predict the onset and severity of belowlevel neuropathic pain after spinal cord injury in rats. Exp Neurol 2008, 212:337-347

82. Hao Y, Collins C: Intrinsic mechanisms for axon regeneration: insights from injured axons in Drosophila. Curr Opin Genet Dev 2017, 44:84-91

83. Sakamoto K, Kadomatsu K: Mechanisms of axon regeneration: the significance of proteoglycans. Biochim Biophys Acta 2017, 1861: 2435-2441

84. Wu D, Klaw MC, Connors T, Kholodilov N, Burke RE, Tom VJ: Expressing constitutively active Rheb in adult neurons after a complete spinal cord injury enhances axonal regeneration beyond a chondroitinase-treated glial scar. J Neurosci 2015, 35:11068-11080

85. Karow M, Sanchez R, Schichor C, Masserdotti G, Ortega F, Heinrich C, Gascon S, Khan MA, Lie DC, Dellavalle A, Cossu G, Goldbrunner R, Gotz M, Berninger B: Reprogramming of pericytederived cells of the adult human brain into induced neuronal cells. Cell Stem Cell 2012, 11:471-476

86. Dore-Duffy P, Katychev A, Wang X, Van Buren E: CNS microvascular pericytes exhibit multipotential stem cell activity. J Cereb Blood Flow Metab 2006, 26:613-624

87. Orr MB, Gensel JC: Spinal cord injury scarring and inflammation: therapies targeting glial and inflammatory responses. Neurotherapeutics 2018, 15:541-553

88. De La Fuente AG, Lange S, Silva ME, Gonzalez GA, Tempfer H, van Wijngaarden P, Zhao C, Di Canio L, Trost A, Bieler L, Zaunmair P, Rotheneichner P, O'Sullivan A, Couillard-Despres S, Errea O, Mae MA, Andrae J, He L, Keller A, Batiz LF, Betsholtz C, Aigner L, Franklin RJM, Rivera FJ: Pericytes stimulate oligodendrocyte progenitor cell differentiation during CNS remyelination. Cell Rep 2017, 20:1755-1764

89. Sena IFG, Paiva AE, Prazeres P, Azevedo PO, Lousado L, Bhutia SK, Salmina AB, Mintz A, Birbrair A: Glioblastoma-activated pericytes support tumor growth via immunosuppression. Cancer Med 2018, 7:1232-1239

90. Wanner IB, Anderson MA, Song B, Levine J, Fernandez A, GrayThompson Z, Ao Y, Sofroniew MV: Glial scar borders are formed by newly proliferated, elongated astrocytes that interact to corral inflammatory and fibrotic cells via STAT3-dependent mechanisms after spinal cord injury. J Neurosci 2013, 33:12870-12886

91. Slezak M, Goritz C, Niemiec A, Frisen J, Chambon P, Metzger D, Pfrieger FW: Transgenic mice for conditional gene manipulation in astroglial cells. Glia 2007, 55:1565-1576

92. Eming SA, Martin P, Tomic-Canic M: Wound repair and regeneration: mechanisms, signaling, and translation. Sci Transl Med 2014, 6: $265 \mathrm{sr} 6$

93. O'Reilly S: Epigenetics in fibrosis. Mol Aspects Med 2017, 54: 89-102

94. Birbrair A, Zhang T, Wang ZM, Messi ML, Mintz A, Delbono O: Type-1 pericytes participate in fibrous tissue deposition in aged skeletal muscle. Am J Physiol Cell Physiol 2013, 305: C1098-C1113

95. Kim KK, Kugler MC, Wolters PJ, Robillard L, Galvez MG, Brumwell AN, Sheppard D, Chapman HA: Alveolar epithelial cell mesenchymal transition develops in vivo during pulmonary fibrosis and is regulated by the extracellular matrix. Proc Natl Acad Sci U S A 2006, 103:13180-13185

96. Zeisberg EM, Tarnavski O, Zeisberg M, Dorfman AL, McMullen JR, Gustafsson E, Chandraker A, Yuan X, Pu WT, Roberts AB, Neilson EG, Sayegh MH, Izumo S, Kalluri R: Endothelial-tomesenchymal transition contributes to cardiac fibrosis. Nat Med 2007, 13:952-961

97. Scholten D, Reichart D, Paik YH, Lindert J, Bhattacharya J, Glass CK, Brenner DA, Kisseleva T: Migration of fibrocytes in fibrogenic liver injury. Am J Pathol 2011, 179:189-198

98. Barnes JL, Glass WF 2nd: Renal interstitial fibrosis: a critical evaluation of the origin of myofibroblasts. Contrib Nephrol 2011, 169: 73-93

99. Greenhalgh SN, Conroy KP, Henderson NC: Healing scars: targeting pericytes to treat fibrosis. QJM 2015, 108:3-7

100. Dulauroy S, Di Carlo SE, Langa F, Eberl G, Peduto L: Lineage tracing and genetic ablation of ADAM12(+) perivascular cells identify a major source of profibrotic cells during acute tissue injury. Nat Med 2012, 18:1262-1270

101. Duffield JS: Cellular and molecular mechanisms in kidney fibrosis. J Clin Invest 2014, 124:2299-2306

102. Kramann R, Schneider RK, DiRocco DP, Machado F, Fleig S, Bondzie PA, Henderson JM, Ebert BL, Humphreys BD: Perivascular 
Gli1+ progenitors are key contributors to injury-induced organ fibrosis. Cell Stem Cell 2015, 16:51-66

103. Bergers G, Song S, Meyer-Morse N, Bergsland E, Hanahan D: Benefits of targeting both pericytes and endothelial cells in the tumor vasculature with kinase inhibitors. J Clin Invest 2003, 111:1287-1295

104. Xiong HQ, Herbst R, Faria SC, Scholz C, Davis D, Jackson EF, Madden T, McConkey D, Hicks M, Hess K, Charnsangavej CA, Abbruzzese JL: A phase I surrogate endpoint study of SU6668 in patients with solid tumors. Invest New Drugs 2004, 22:459-466
105. Talac R, Friedman JA, Moore MJ, Lu L, Jabbari E, Windebank AJ, Currier BL, Yaszemski MJ: Animal models of spinal cord injury for evaluation of tissue engineering treatment strategies. Biomaterials 2004, 25:1505-1510

106. Courtine G, Bunge MB, Fawcett JW, Grossman RG, Kaas JH, Lemon R, Maier I, Martin J, Nudo RJ, Ramon-Cueto A, Rouiller EM, Schnell L, Wannier T, Schwab ME, Edgerton VR: Can experiments in nonhuman primates expedite the translation of treatments for spinal cord injury in humans? Nat Med 2007, 13:561-566 